\title{
Seasonal and spatial variability of dimethylsulfoniopropionate (DMSP) in the Mediterranean seagrass Posidonia oceanica
}

\author{
A.V. Borges*, W. Champenois \\ Chemical Oceanography Unit, University of Liège, Liège, Belgium
}

\section{A R T I C L E I N F O}

\section{Article history:}

Received 27 November 2014

Received in revised form 26 May 2015

Accepted 30 May 2015

Available online 4 June 2015

\section{Keywords:}

Mediterranean sea

Posidonia oceanica

Dimethylsulfoniopropionate

Dimethylsulfide

\begin{abstract}
A B S T R A C T
We investigated for the first time the occurrence of dimethylsulfoniopropionate (DMSP) in the leaves of Posidonia oceanica and we report its variability during 4 sampling periods covering the seasonal cycle (February, June, August and November) and along a gradient from $10 \mathrm{~m}$ to $30 \mathrm{~m}$ depth. The $P$. oceanica leaf DMSP content expressed per mass of dry weight (dw) ranged from 0.1 to $33.9 \mu \mathrm{mol} \mathrm{g}_{\mathrm{dw}}{ }^{-1}$ and averaged $5.0 \mu \mathrm{molg}_{\mathrm{dw}^{-1}}{ }^{-}$. It was higher than the DMSP content of roots and rhizomes that averaged $\sim 0.5 \mu \mathrm{mol} \mathrm{g}_{\mathrm{dw}^{-1}}{ }^{-1}$. The leaf DMSP content showed seasonal variations, being highest in summer when primary production and biomass of $P$. oceanica were also highest. In August, the leaf DMSP content showed variations with depth, increasing from $30 \mathrm{~m}$ to $10 \mathrm{~m}$ depth. In summer, the leaf DMSP content was highest in the youngest sections of leaves (closest to base) than in the older ones (closest to apex). The seasonal and depth distribution suggest that the DMSP leaf content is positively related to irradiance, hence, we hypothesize that DMSP in P. oceanica plays a role as an antioxidant against reactive oxygen species, although we cannot unambiguously exclude other potential roles such as grazer deterrent. The average leaf DMSP content of $P$. oceanica is modest compared to high DMSP producing macroalgae and phytoplankton. Yet, the integrated DMSP stock associated to the meadows of $P$. oceanica is very large due to its enormous biomass, and at the community level it is 2 orders of magnitude higher than the potential integrated DMSP stock related to phytoplankton in the same area.
\end{abstract}

(c) 2015 Elsevier B.V. All rights reserved.

\section{Introduction}

Dimethylsulfoniopropionate (DMSP) is produced by a variety of marine organisms including phytoplankton (Keller et al., 1989; Stefels et al., 2007), macroalgae and invertebrates (Van Alstyne and Puglisi 2007). DMSP has also been reported in numerous higher plants (Paquet et al., 1995), but usually in low concentrations. Out of the 177 species of terrestrial angiosperms studied by Paquet et al. (1995), only seven had a DMSP content per mass of dry weight (dw) between 0.1 and $1 \mu \mathrm{molg}_{\mathrm{dw}}{ }^{-1}$, all the others being characterized by undetectable DMSP levels. Only a few species of higher plants have a high DMSP content, either strictly terrestrial plants such as sugar cane (Saccharum) and Wollastonia biflora and intertidal plants such as some species of Spartina (Otte et al., 2004; Dacey et al., 1987). The only study so far that has investigated the occurrence of DMSP in seagrasses was carried out by Dacey et al. (1994) who attributed the occurrence of DMSP in samples from three species (Halodule wrightii, Syringodium filiforme, Thalas-

\footnotetext{
* Corresponding author. Fax: +32 43669729

E-mail address: alberto.borges@ulg.ac.be (A.V. Borges).
}

sia testudinum) to epiphyte algae and not to the actual tissue of the seagrasses. Jean et al. (2006) hypothesized that the high dissolved DMSP (DMSPd) concentrations in coastal bays along the French Mediterranean coastline could be related to the presence of the marine phanerogam Posidonia oceanica meadows, although the DMSP content of $P$. oceanica tissues was not measured by these authors.

The content of DMSP in marine autotrophs is highly variable (Table 1). For phytoplankton, the DMSP content is highest in Dinoflagellates, Chrysophytes and Haptophytes $\left(>100 \mu \mathrm{molg}_{\mathrm{dw}}{ }^{-1}\right)$, extremely low in Prochlorophytes and Cyanophytes $\left(<0.1 \mu \mathrm{molg}_{\mathrm{dw}}{ }^{-1}\right)$, and intermediary in Prasinophytes and diatoms. In most red, brown and green algae, the DMSP content is low or below detection limit (d.l.), with the exception of two species of red algae, and the group of Ulvales (Table 1). The DMSP content of three Spartina species, a halophyte abundant in salt marshes, is high and falls within the range for different phytoplankton groups, although numerous other salt-marsh plants (including several other species of Spartina) have undetectable levels of DMSP.

Several physiological and ecological roles have been attributed to DMSP (Table 2). Some are common to phytoplankton, macroal- 
Table 1

Dimethylsulfoniopropionate (DMSP) content per dry wet $(\mathrm{dw})\left(\mu \mathrm{molg} \mathrm{dw}^{-1}\right)$ in major phytoplanktonic groups based on Stefels et al. (2007), macroalgae based on Van Alstyne and Puglisi (2007), intertidal marsh plants based on Otte et al. (2004) and Dacey et al. (1987). The values for phytoplankton initially given in mols:molC were converted into dry weight using a carbon to total dry weight of $50 \%$ (Reynolds 2006). The values for Spartina given initially in wet weight were converted to dry weight using a water content of $73 \%$ (Otte et al., 2004). d.l. = Detection limit.

\begin{tabular}{|c|c|c|}
\hline & & $\operatorname{DMSP}\left(\mu \mathrm{molg}_{\mathrm{dw}}{ }^{-1}\right)$ \\
\hline \multicolumn{3}{|l|}{ Phytoplankton } \\
\hline Diatoms & & $14 \pm 21$ \\
\hline Chrysophytes & & $317 \pm 250$ \\
\hline Dinoflagellates & & $367 \pm 533$ \\
\hline Prasinophytes & & $83 \pm 117$ \\
\hline Haptophytes & & $183 \pm 117$ \\
\hline Prochlorophytes/Cyanophytes & & $0.03 \pm 0.07$ \\
\hline \multicolumn{3}{|l|}{ Macroalgae } \\
\hline \multicolumn{3}{|l|}{ Red algae } \\
\hline & $\begin{array}{l}\text { Polysiphonia sp. and } \\
\text { Halopytis sp. }\end{array}$ & $23 \pm 122$ \\
\hline & Other red algae & $<2$ \\
\hline Brown algae & & $<3$ \\
\hline \multicolumn{3}{|l|}{ Green algae } \\
\hline & Ulvales & $145 \pm 150$ \\
\hline & Caulerpales & $<$ d.l. \\
\hline & Dasycladales & $<$ d.l. \\
\hline & Siphonocladales & $<\mathrm{d} .1$. \\
\hline \multirow{2}{*}{\multicolumn{3}{|c|}{$\begin{array}{l}\text { Higher plants } \\
\text { Intertidal marsh plants }\end{array}$}} \\
\hline & & \\
\hline & Spartina anglica & $15-185$ \\
\hline & Spartina alterniflora & $33-259$ \\
\hline & Spartina foliosa & $26-30$ \\
\hline & Spartina patents & $<$ d.l. \\
\hline & Spartina cynosuroides & $<$ d.l. \\
\hline & Distichlis spicata & $<$ d.l. \\
\hline & Juncus sp & $<$ d.l. \\
\hline & Salicornia europeae & $<$ d.l. \\
\hline & Phragmites communis & $<$ d.l. \\
\hline & Rhizophora mangle & $<$ d.l. \\
\hline
\end{tabular}

Table 2

Functions of dimethylsulfoniopropionate (DMSP) reported in phytoplankton (based on Stefels et al., 2007), macroalgae (based on Van Alstyne and Puglisi 2007) and Spartina (based on Otte et al., 2004).

$N / A=$ Not applicable

$N / T=$ Not tested.

\begin{tabular}{|c|c|c|c|}
\hline & Phytoplankton & Macroalgae & Spartina \\
\hline Osmolyte and osmoregulation & $\mathrm{x}$ & $\mathrm{x}$ & $\mathrm{x}$ \\
\hline Herbivore deterrent & $\mathrm{x}$ & $\mathrm{x}$ & $\mathrm{x}$ \\
\hline Cryoproctectant & $\mathrm{x}$ & $\mathrm{x}$ & $\mathrm{x}$ \\
\hline $\begin{array}{l}\text { Antioxidant function against reactive } \\
\text { oxygen species (ROS) }\end{array}$ & $\mathrm{x}$ & $\mathrm{x}$ & $\mathrm{X}$ \\
\hline $\begin{array}{l}\text { Carbon }(\mathrm{C}) \text { and nitrogen }(\mathrm{N}) \text { overflow } \\
\text { mechanism }\end{array}$ & $\mathrm{x}$ & $N / T$ & $\mathrm{X}$ \\
\hline Antibiotic (virus and bacteria) & $\mathrm{x}$ & $N / T$ & $N / T$ \\
\hline Antifouling against epiphytes & $N / A$ & $N / T$ & $\mathrm{X}$ \\
\hline Sulfide $\left(\mathrm{H}_{2} \mathrm{~S}\right)$ detoxification & $N / A$ & $N / T$ & $\mathrm{X}$ \\
\hline
\end{tabular}

$x=$ Cited in literature

$N / A=$ Not applicable

$N / T=$ Not tested.

gae and Spartina such as osmolyte, osmoregulator, herbivore deterrent, cryoprotectant and antioxidant against reactive oxygen species (ROS). Other possible roles could be common to phytoplankton, macroalgae and Spartina but have not been hypothesized nor tested in all, such as overflow mechanism for carbon (C) or antibiotic against viruses or bacteria. Some are not applicable to phytoplankton such as antifouling against epiphytes and $\mathrm{H}_{2} \mathrm{~S}$ detoxification.

Here, we investigate, for the first time, the spatial and seasonal variability of DMSP in the marine phanerogam P. oceanica. This seagrass is endemic of the Mediterranean Sea, present from near-surface to $\sim 40 \mathrm{~m}$ depth, characterized by high gross primary production (GPP) (e.g. Champenois and Borges 2012) and by belowground and above-ground biomass that exceeds those of other seagrasses (Green and Short 2003). The aims of this study are to determine if DMSP occurs in $P$. oceanica tissues and if there are variations of DMSP content within the plant (among leaves and along the length of leaves), among individual shoots, with depth and with season. Based on these variations we discuss the possible physiological roles that DMSP could play in P. oceanica.

\section{Material and methods}

\subsection{Sampling}

Sampling was carried out in northern part of the Bay of Revellata in Corsica $\left(8.725^{\circ} \mathrm{E} 42.580^{\circ} \mathrm{N}\right)$ close to the Stareso research station in a dense and healthy $P$. oceanica meadow. Due to the steep rocky shores, the meadow starts at about $8 \mathrm{~m}$ depth and extends to $38 \mathrm{~m}$. Background information on the meadow in the Bay of Revellata is given by Gobert et al. (1995).

We carried out a first sampling in August 2012 aiming at determining the dimethylsulfide (DMS) and DMSPd distribution in the water column and related benthic fluxes with incubation chambers. Based on the obtained DMS and DMSPd results (hereafter) and on preliminary determination of DMSP leaf content of $P$. oceanica on a very limited number of samples (not shown), we setup a more detailed study of the DMSP content in tissues of $P$. oceanica to investigate variability among and within shoots as well as seasonally and along a depth gradient.

Between 2 and 3 shoots of $P$. oceanica were collected by selfcontained underwater breathing apparatus (scuba) at 10, 15, 20, 25 and $30 \mathrm{~m}$ on 28/11/2012, 14/02/2013, 3/06/2013, and 13/08/2013. Shoots of $P$. oceanica have typically between 5 and 10 leaves (Gobert et al., 1995). The leaves were sorted into 3 classes: the two most external leaves on each side (called "external"), the following two leaves on each side (called "intermediary"), all of the following leaves (called "internal"). The leaves were scrapped with a razor blade to remove epiphytes (Dauby and Poulicek 1995), and cut into sections of $10 \mathrm{~cm}$ starting at the base of the leaf. They were dried at $60{ }^{\circ} \mathrm{C}$ for $48 \mathrm{~h}$, wrapped in aluminum foil and stored dry until further analysis, as recommended for the analysis of the DMSP content in macrophytes (Karsten et al., 1994; Van Alstyne et al., 2003). The length of the leaf is given from the base $(0 \mathrm{~cm})$, increasing towards the apex. The leaf grows from the base, so the younger section of the leaf corresponds to the first section $(0-10 \mathrm{~cm})$ according to our convention. The sampling was carried out to collect only the shoots avoiding to remove the roots to minimize damage of the meadow. When roots and rhizomes were accidentally removed, they were collected and stored dried, resulting in a more limited amount of samples.

In August 2012, water samples were collected for the determination of DMS concentration in the water column above and within the canopy of the $P$. oceanica meadow at $10 \mathrm{~m}$ depth. The evolution of the DMS and DMSPd concentrations in an incubation chamber deployed on the sediment and enclosing a $P$. oceanica shoot was also determined during a $24 \mathrm{~h}$ cycle starting at dawn, using the same apparatus as for $\mathrm{O}_{2}$ incubations described in details by Champenois and Borges (2012). Sampling was done three times during the $24 \mathrm{~h}$ (dawn, dusk and dawn the day after) by scuba diving and water samples collected in $60 \mathrm{~mL}$ plastic syringes. For the determination of DMS, aliquots of $10 \mathrm{~mL}$ were transferred within $30 \mathrm{~min}$ after sampling to $20 \mathrm{~mL}$ borosilicate vials, sealed with gas tight polytetrafluoroethylene coated silicone septa and stored in the dark at $4{ }^{\circ} \mathrm{C}$ until further analysis (within $12 \mathrm{~h}$ ). For the determination of DMSPd, aliquots were filtered, within $30 \mathrm{~min}$ after 
sampling, by gravity on $25 \mathrm{~mm} \mathrm{GF/F} \mathrm{(Whatman)} \mathrm{glass} \mathrm{fiber} \mathrm{filters}$ as recommended by Kiene and Slezak (2006). A higher volume was filtered $(10 \mathrm{~mL})$ than originally recommended by Kiene and Slezak (2006) $(3.5 \mathrm{~mL})$, and filtrate was stored in $20 \mathrm{~mL}$ borosilicate vials, to which was immediately added $50 \mu \mathrm{L}$ of $\mathrm{H}_{3} \mathrm{PO}_{4}(50 \%)$, sealed with gas tight polytetrafluoroethylene coated silicone septa and stored in the dark at room temperature until further analysis. The change of concentration versus time was linearly correlated for DMS $\left(r^{2}=0.974, p=0.1033, n=3\right)$ and for DMSPd $\left(r^{2}=0.982\right.$, $p=0.0858, n=3$ ). The DMS and DMSPd fluxes were computed from the slope of the regression and the geometry of the chamber, as described for $\mathrm{O}_{2}$ by Champenois and Borges (2012).

\subsection{Chemical analysis}

A primary solution of DMSP with a concentration of $2.19 \mathrm{mmol} \mathrm{L}^{-1}$ was prepared from a solid DMSP standard (Research Plus Inc) dissolved in ultrapure (Type 1) Milli-Q (Millipore) water. This solution was stored at $4{ }^{\circ} \mathrm{C}$, and according to Stefels (2009) is stable during several weeks. A working solution was prepared by diluting the primary stock solution of DMSP 100 -fold. Seven dilutions were prepared from the working solution providing 8 standards $(21.90,17.50,13.10,8.77,4.39,2.19,1.75$ and $0.88 \mu \mathrm{mol} \mathrm{L}^{-1}$ ). A volume of $5 \mathrm{~mL}$ of each standard was transferred to borosilicate $10 \mathrm{~mL}$ vials to which were added $\sim 1.2 \mathrm{~g}$ of $\mathrm{NaOH}$ (6 pellets), and then sealed with gas tight polytetrafluoroethylene coated silicone septa. Five replicates were prepared for each standard. About $10 \mathrm{mg}$ of each leaf sample were weighed, cut into small pieces with scissors within a $10 \mathrm{~mL}$ borosilicate vial to which was added $5 \mathrm{~mL}$ of Milli-Q water and $\sim 1.2 \mathrm{~g}$ of $\mathrm{NaOH}$ ( 6 pellets), and then sealed with gas tight polytetrafluoroethylene coated silicone septa. For roots and rhizomes sample weight was higher, $20-30 \mathrm{mg}$, depending on the available material. The $\mathrm{NaOH}$ digestion of the standards and samples lasted about $18 \mathrm{~h}$ at room temperature, under gentle agitation (rotating table).

A volume of $50 \mu \mathrm{l}$ of gas was sampled from the headspace of either the standard or sample vials with a gas-tight syringe (Hamilton) and injected directly to the head of the chromatographic column of an Agilent 7890A gas chromatograph (GC) fitted with a flame photometric detector (FPD) and a flame ionization detector (FID). The calibration curve of the FPD and the FID was established daily (for each batch of samples) by fitting a quadratic curve and a linear regression line, respectively. The coefficient of variation (CV) was typically $\pm 10 \%$ and $\pm 30 \%$ for standards ( 5 replicates) and samples (2 replicates), respectively. These CV values are comparable to those reported with similar methods on Spartina (e.g. McFarlin and Alber 2013). One possible source of variation is the gas volume of vials that was checked on 90 random vials and was found to have a CV of $\pm 1.5 \%$. The d.l. was $0.25 \mu \mathrm{mol} \mathrm{g}_{\mathrm{dw}^{-1}}$.

For the determination of the DMS in seawater (August 2012), we followed standard protocols (Stefels 2009) using a purge and trap system with Tenax-TA mounted on a cooling-heating Peltier system. The water sample was purged for $15 \mathrm{~min}$ with a flow of $\mathrm{N}_{2}$ and trapped on Tenax-TA at $-10^{\circ} \mathrm{C}$, then released on to the GC column by heating to $70^{\circ} \mathrm{C}$. The GC was a SRI 8610C GC fitted with FPD and FID with a Chromosil 330 packed column (Supelco) in an oven kept at $60^{\circ} \mathrm{C}$. The carrier gas was $\mathrm{N}_{2}\left(40 \mathrm{~mL} \mathrm{~min}^{-1}\right)$. The FID was kept at $150^{\circ} \mathrm{C}$ with a $\mathrm{H}_{2}$ flow of $25 \mathrm{~mL} \mathrm{~min}^{-1}$, a compressed air flow of $250 \mathrm{~mL} \mathrm{~min}^{-1}$ and a make-up $\left(\mathrm{N}_{2}\right)$ flow of $15 \mathrm{~mL} \mathrm{~min}^{-1}$. The FPD was kept at $250^{\circ} \mathrm{C}$ with a $\mathrm{H}_{2}$ flow of $60 \mathrm{~mL} \mathrm{~min}^{-1}$, a compressed air flow of $100 \mathrm{~mL} \mathrm{~min}^{-1}$ and a make-up $\left(\mathrm{N}_{2}\right)$ flow of $1 \mathrm{~mL} \mathrm{~min}^{-1}$.

For the determination of DMSPd in the seawater (incubations in August 2012), we followed standard protocols (Stefels 2009) of $\mathrm{NaOH}$ hydrolysis overnight, followed by DMS analysis by purge and trap. The DMS was purged with $\mathrm{He}\left(180 \mathrm{~mL} \mathrm{~min}^{-1}\right)$ during $20 \mathrm{~min}$ and trapped on a polytetrafluoroethylene loop in liquid $\mathrm{N}_{2}$, after which the loop was immersed into boiling water and the gas flow diverted to the chromatographic column. For the determination of DMSP and DMS in the water column, calibrations were carried out using the protocols given by Stefels (2009).

For the DMSP content in leaf/rhizome/root samples and the DMSP in the water column (August 2012), we used an Agilent 7890A GC equipped with a FID and a FPD, although for all samples we relied on the FPD signal. The carrier gas (He, $\left.2 \mathrm{~mL} \mathrm{~min}^{-1}\right)$ was split $30 \%$ to the FID and $70 \%$ to the FPD. The FID was kept at $325^{\circ} \mathrm{C}$ with a $\mathrm{H}_{2}$ flow of $50 \mathrm{~mL} \mathrm{~min}^{-1}$, a synthetic air flow of $400 \mathrm{~mL} \mathrm{~min}^{-1}$ and a make up $\left(\mathrm{N}_{2}\right)$ flow of $15 \mathrm{~mL} \mathrm{~min}^{-1}$. The FPD was kept at $250^{\circ} \mathrm{C}$ with a $\mathrm{H}_{2}$ flow of $50 \mathrm{~mL} \mathrm{~min}^{-1}$, a synthetic air flow of $60 \mathrm{~mL} \mathrm{~min}^{-1}$ and a make up $\left(\mathrm{N}_{2}\right)$ flow of $1 \mathrm{~mL} \mathrm{~min}^{-1}$. The capillary column (CP-Sil $5 \mathrm{CB}, 30 \mathrm{~m}$ long, $0.32 \mathrm{~mm}$ internal diameter, $0.5 \mu \mathrm{m}$ film thickness, Chromatographie Service $\mathrm{GmbH}$ ) was kept at $60^{\circ} \mathrm{C}$.

\subsection{Statistical analysis}

All data were analysed by analysis of variance. Our design involved five factors, and corresponded to a split-plot design with two between-subjects factors and two within-subjects factors including one covariate (Quinn and Keough 2002). The temporal and spatial (i.e. depth) components of the design were fully crossed. The subjects were the shoots, with three random replicate shoots nested within each depth and date. Within-subject factors were leaf classes ("external", "intermediary", "internal") and leaf section (every $10 \mathrm{~cm}$ ) as a covariate. The response variable was DMSP concentration in $\mu \mathrm{molg}_{\mathrm{dw}}{ }^{-1}$ and was transformed to $\log 10(x+1)$ to improve normality and homogeneity of variances between treatments. Statistics were performed using Systat 11.

\subsection{Other data}

Biometric data were not acquired during this study, hence, we used leaf biomass data acquired as described by Champenois and Borges (2012) during 21 samplings from August 2006 to August 2012 at $10 \mathrm{~m}$ depth. Data were bin averaged to provide monthly averages. Similarly, monthly averages of GPP are provided for the 2006-2013 period derived from the mass balance of $\mathrm{O}_{2}$ from data acquired at mooring at $10 \mathrm{~m}$ depth, as described by Champenois and Borges (2012). The chlorophyll-a (Chl-a) concentration data were acquired daily from August 2006 to December 2013 with a fluorometer moored at $4.5 \mathrm{~m}$ on the mooring over the $P$. oceanica meadow at $10 \mathrm{~m}$ depth as described in details by Champenois and Borges (2012).

\section{Results}

The DMSP content in $P$. oceanica leaves was analyzed in 458 leaf samples that were replicated 2-4 times, totaling 1440 analysis. The DMSP leaf content was detectable in all samples, and values ranged from 0.1 to $33.9 \mu \mathrm{mol} \mathrm{g}_{\mathrm{dw}}{ }^{-1}$ and averaged $5.0 \mu \mathrm{mol} \mathrm{g} \mathrm{dw}^{-1}$. The variations of leaf DMSP content as a function of season, depth, and along the leaf length were found to be statistically significant (Table 3). The leaf DMSP content was not significantly different among the different classes within a given shoot ("external", "internal" and "intermediary") and among the different sampled shoots (2-3) collected at a given depth and season (Table 3). Hence, we averaged the leaf DMSP content by $10 \mathrm{~cm}$ sections for all leaf classes and for all sampled shoots for a given depth and a given season. The leaf DMSP content was more variable in the first $30 \mathrm{~cm}$ of the leaf (from the base), and relatively invariant in leaf sections $>30 \mathrm{~cm}$ (see hereafter). Given that the first $30 \mathrm{~cm}$ of leaves were sampled during all seasons and at all depths and that in February and November leaf length was $<40 \mathrm{~cm}$ in all shoots, the data were further averaged 
Table 3

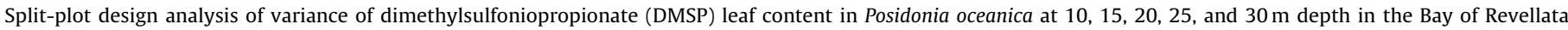

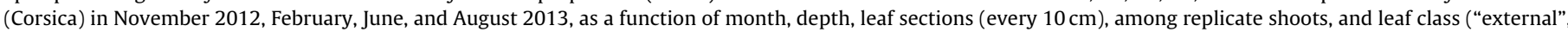
"intermediate", and "internal").

\begin{tabular}{|c|c|c|c|c|c|}
\hline & Sum of squares & Degrees of freedom & Mean square & $f$-Ratio & $p$ \\
\hline Month & 9.0 & 3 & 3.00 & 28.0 & $<0.001$ \\
\hline Depth & 6.3 & 4 & 1.58 & 14.7 & $<0.001$ \\
\hline Month $\times$ depth & 3.7 & 11 & 0.33 & 3.1 & 0.018 \\
\hline Leaf section & 1.3 & 1 & 1.28 & 11.9 & 0.003 \\
\hline Shoot (month, depth) & 1.8 & 17 & 0.11 & & \\
\hline Leaf class & 1.1 & 2 & 0.56 & 2.8 & 0.070 \\
\hline Month $\times$ leaf class & 0.2 & 5 & 0.04 & 0.2 & 0.964 \\
\hline Depth $\times$ leaf class & 2.3 & 7 & 0.33 & 1.7 & 0.146 \\
\hline Month $\times$ month $\times$ leaf class & 10.2 & 22 & 0.46 & 2.4 & 0.009 \\
\hline Shoot (month, depth) $\times$ leaf class & 8.0 & 41 & 0.20 & & \\
\hline Error & 54.8 & 1477 & 0.04 & & \\
\hline
\end{tabular}

Table 4

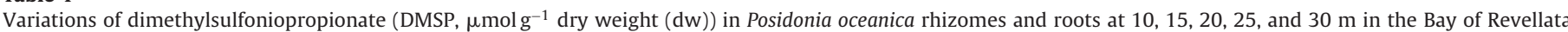

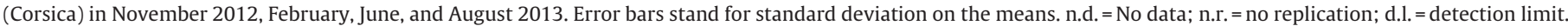

\begin{tabular}{|c|c|c|c|c|c|c|c|c|}
\hline & \multicolumn{2}{|l|}{ February } & \multicolumn{2}{|l|}{ June } & \multicolumn{2}{|l|}{ August } & \multicolumn{2}{|l|}{ November } \\
\hline & Rhizome & Root & Rhizome & Root & Rhizome & Root & Rhizome & Root \\
\hline $10 \mathrm{~m}$ & $0.09 \pm 0.01$ & n.d. & $0.32 \pm 0.13$ & n.d. & $0.23 \pm 0.01$ & n.d. & $<\mathrm{d} .1$. & n.d. \\
\hline $15 \mathrm{~m}$ & $0.17 \pm 0.08$ & n.d. & $2.27 \pm 0.22$ & $2.16 \pm 1.29$ & $0.28 \pm 0.07$ & 0.66 (n.r.) & $<$ d.l. & n.d. \\
\hline $20 \mathrm{~m}$ & $0.19 \pm 0.02$ & n.d. & $0.27 \pm 0.14$ & n.d. & $0.34 \pm 0.16$ & n.d. & $<$ d.l. & $<$ d.l. \\
\hline $25 \mathrm{~m}$ & $0.23 \pm 0.01$ & n.d. & $1.46 \pm 1.13$ & 0.06 (n.r.) & $0.31 \pm 0.06$ & n.d. & $0.29 \pm 0.02$ & n.d. \\
\hline $30 \mathrm{~m}$ & $0.14 \pm 0.01$ & $0.47 \pm 0.01$ & 0.36 (n.r.) & 0.51 (n.r.) & $0.86 \pm 0.06$ & 0.70 (n.r.) & $0.47 \pm 0.24$ & 0.54 (n.r.) \\
\hline
\end{tabular}

for the first $30 \mathrm{~cm}$ of the leaves. Fig. 1 shows the seasonal variations of the resulting average leaf DMSP content at different depths. In February and November, the leaf DMSP content was low at all depths with values of $\sim 2.0 \mu \mathrm{molg}_{\mathrm{dw}}{ }^{-1}$, except for the sample at $20 \mathrm{~m}$ in November that was higher with a value of $\sim 4.9 \mu \mathrm{mol} \mathrm{g}_{\mathrm{dw}^{-1}}{ }^{-1}$. In June, the leaf DMSP content remained close to the values of February at $15 \mathrm{~m}$ and $30 \mathrm{~m}$ depth, but strongly increased at $10 \mathrm{~m}$, $20 \mathrm{~m}$ and $25 \mathrm{~m}$ depth to levels of $\sim 8.5 \mu \mathrm{molg}_{\mathrm{dw}}{ }^{-1}$. In August, the leaf DMSP content increased compared to June at $10 \mathrm{~m}, 15 \mathrm{~m}$ and $30 \mathrm{~m}$, but decreased at $20 \mathrm{~m}$ and $25 \mathrm{~m}$. The general pattern was a higher leaf DMSP content during summer (June and August) compared to winter (February and November) concurrently with the increase of leaf biomass and GPP as shown by the average seasonal cycles at $10 \mathrm{~m}$ (Fig. 1 ).

In August, the leaf DMSP content decreased with depth from $10 \mathrm{~m}$ to $20 \mathrm{~m}$, and remained constant onwards to $30 \mathrm{~m}$ (Fig. 2). In August, the leaf DMSP content was higher in the first $20 \mathrm{~cm}$ from the base of the leaves than in the rest of the leaf where the DMSP was relatively constant with length, at all depths (Fig. 3). These leaf DSMP patterns along leaf length were not as clear at all depths in June and absent in February and November (data not shown).

The DMSP content was determined in 30 rhizome and 8 root $P$. oceanica samples, based on 0-2 replicates, totaling 42 and 14 analysis, respectively (Table 4 ). The rhizome DMSP content ranged between <d.l. and $2.3 \mu \mathrm{molg}_{\mathrm{dw}^{-1}}$ and averaged $0.4 \mu \mathrm{molg}_{\mathrm{dw}^{-1}}{ }^{-1}$. The root DMSP content ranged between $<$ d.l. and $2.2 \mu \mathrm{mol} \mathrm{g}_{\mathrm{dw}}{ }^{-1}$ and averaged $0.6 \mu \mathrm{molg}_{\mathrm{dw}}{ }^{-1}$. There were no seasonal nor depth variations in the rhizome and root DMSP content.

The DMS concentration in August 2012 over the $P$. oceanica meadow at $10 \mathrm{~m}$ depth was $\sim 8 \mathrm{nmol} \mathrm{L}^{-1}$ at $1 \mathrm{~m}$ and $5 \mathrm{~m}$, but was highly variable in the water within the seagrass meadow ranging between 5 and $32 \mathrm{nmol} \mathrm{L}^{-1}$ as sampled on several occasions during 3 days (Fig. 4). The DMS and DMSPd concentration increased linearly in time within the incubation chamber enclosing a $P$. oceanica shoot (not shown), yielding a net accumulation rate of $17 \mu \mathrm{mol} \mathrm{m}^{-2}$ day $^{-1}$ and $617 \mu \mathrm{mol} \mathrm{m}^{-2}$ day $^{-1}$, respectively. During the course of the incubation, DMS increased from 14 to $28 \mathrm{nmol}$ $\mathrm{L}^{-1}$, and DMSPd from 877 to $1379 \mathrm{nmol} \mathrm{L}^{-1}$.

\section{Discussion}

In the only previous study on the occurrence of DMSP in seagrasses, carried out on 3 species (Halodule wrightii, Syringodium filiforme, Thalassia testudinum), the DMSP content of samples was attributed to epiphyte algae and not to the actual tissue of the seagrasses (Dacey et al., 1994). The occurrence of higher DMSP in our samples in surface than at depth and in summer than in winter could be due to a contamination of DMSP from epiphytes. We removed the epiphytes from the $P$. oceanica leaves with a razor blade, and this technique was shown in a previous dedicated study to effectively remove all epiphytes (macroalgae and diatoms) by examination of scrapped leaves with scanning electron microscopy (Dauby and Poulicek 1995). Further, the young sections of the $P$. oceanica leaf (closest to the base) are devoid of epiphytes that are only abundant in the older leaf sections towards the apex (Cebrian et al., 1999). DMSP was detected in all leaf sections and was in fact more abundant in the younger leaf sections that were, in principle, devoid of epiphytes. Epiphyte flora growing on P. oceanica in the Bay of Revellata is dominated in terms of biomass by red coralline algae (Jacquemart and Demoulin 2006) that have a low DMSP content $<0.2 \mu \mathrm{molg}_{\mathrm{dw}}{ }^{-1}$ (Kamenos et al., 2008). Finally, DMSP was detected $P$. oceanica leaves whatever the season, although epiphytes are absent in winter (Lepoint et al., 2007). We conclude that epiphytes were absent from the leaves that were analyzed and that the detected DMSP was from $P$. oceanica tissues and not a contamination from epiphyte residues. Due to logistic constraints, the samples for DMSP determination needed to be preserved prior to GC analysis and we applied the protocol of Karsten et al. (1994) consisting on drying material for $48 \mathrm{~h}$ at $60^{\circ} \mathrm{C}$ in an oven. Karsten et al. (1994) and Van Alstyne et al. (2003) showed that the DMSP content of macroalgae increases in dried material compared to fresh material, although this was not specifically tested for angiosperms such as $P$. oceanica.

Among the different physiological and ecological roles that DMSP could play in P. oceanica some can be excluded. The role as a cryoprotectant can be excluded as $P$. oceanica is present in areas with minimal temperatures $>9{ }^{\circ} \mathrm{C}$. DMSP is a compatible solute and 

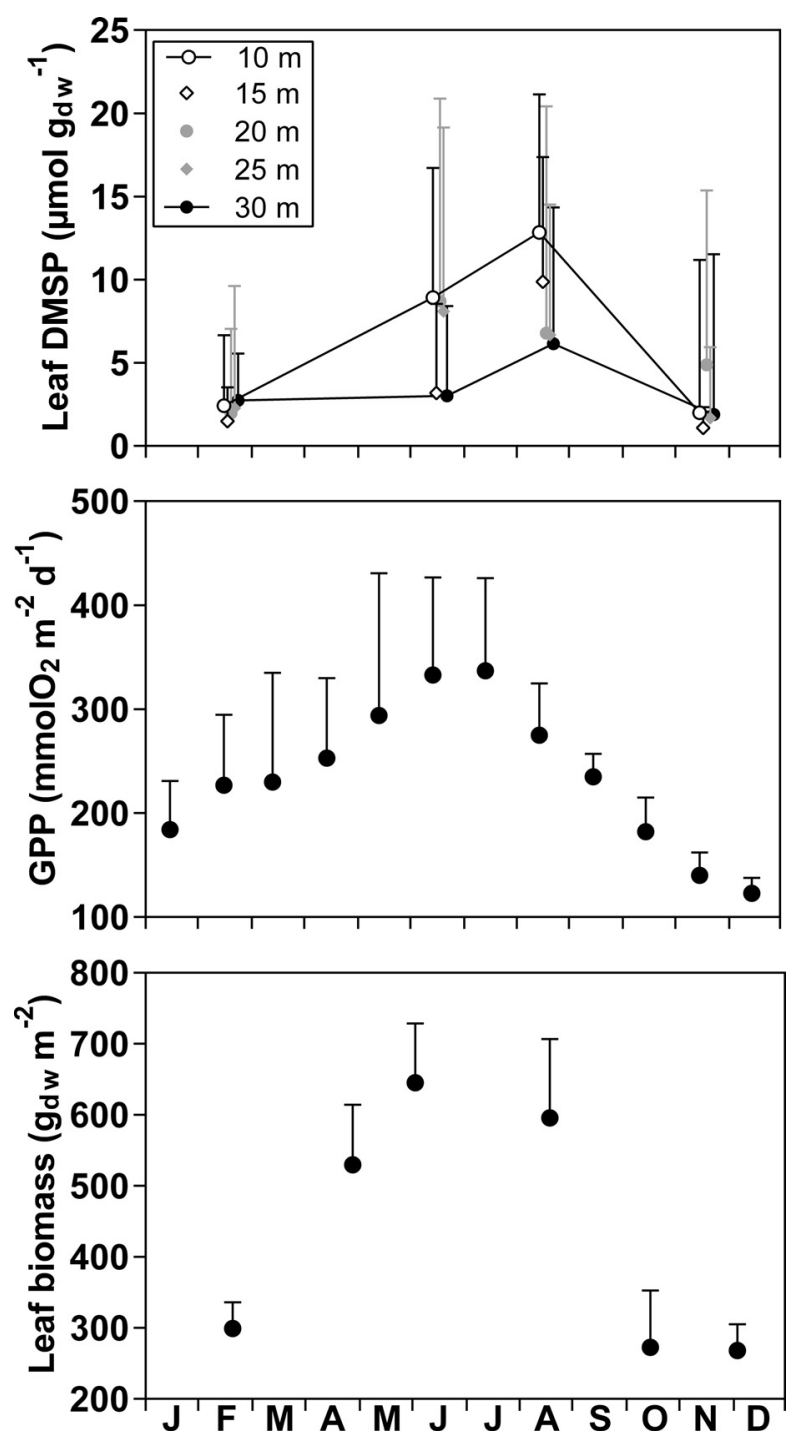

Fig. 1. Variations of dimethylsulfoniopropionate (DMSP, $\mu \mathrm{mol} \mathrm{g}^{-1}$ dry weight (dw)) in Posidonia oceanica leaves at 10,15,20,25, and $30 \mathrm{~m}$ depth in the Bay of Revellata (Corsica) in November 2012, February, June, and August 2013, of mean monthly gross primary production (GPP, $\mathrm{mmolO}_{2} \mathrm{~m}^{-2} \mathrm{~d}^{-1}$ ) for 2006-2013, and of mean $P$. oceanica leaf biomass ( $\mathrm{gdw} \mathrm{m}^{-2}$ ) collected in 2006-2012. The DMSP data points per depth were shifted in time for readability, but all depths were collected at same date. Error bars stand for standard deviation on the means.

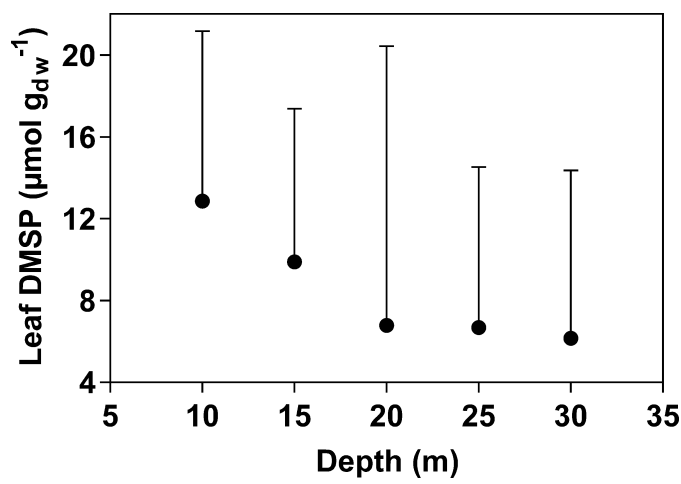

Fig. 2. Variations of dimethylsulfoniopropionate (DMSP, $\mu \mathrm{mol} \mathrm{g}^{-1}$ dry weight (dw)) in Posidonia oceanica leaves as a function of depth in the Bay of Revellata (Corsica) in August 2013. Error bars stand for standard deviation on the means.

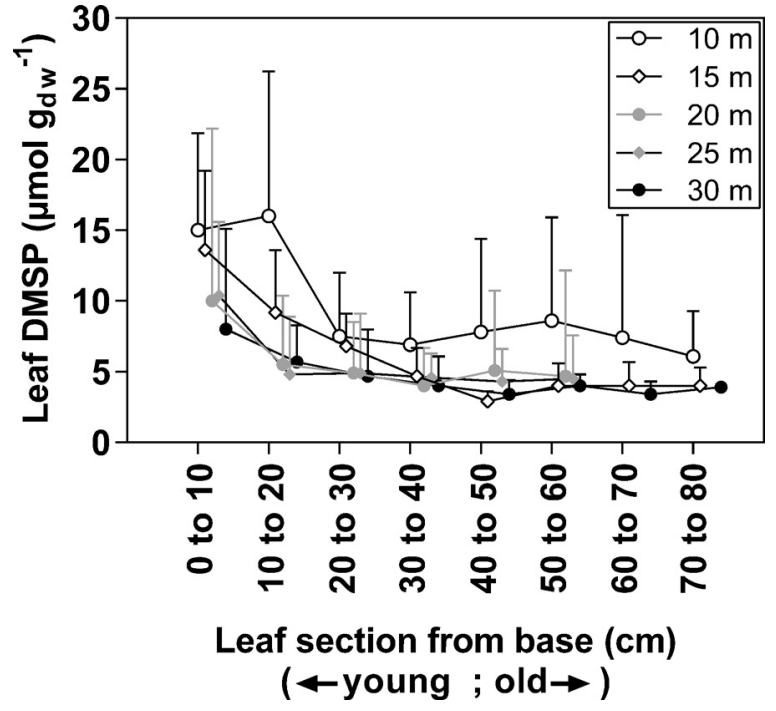

Fig. 3. Variations of dimethylsulfoniopropionate (DMSP, $\mu \mathrm{mol} \mathrm{g}{ }^{-1}$ dry weight (dw)) in Posidonia oceanica leaves as a function of leaf sections (every $10 \mathrm{~cm}$ ) at $10,15,20$ 25 , and $30 \mathrm{~m}$ in the Bay of Revellata (Corsica) in August 2013. The length of the leaf is given from the base $(0 \mathrm{~cm})$, increasing towards the apex, the younger sections of the leaf corresponds to the first section $(0-10 \mathrm{~cm})$. Error bars stand for standard deviation on the means.

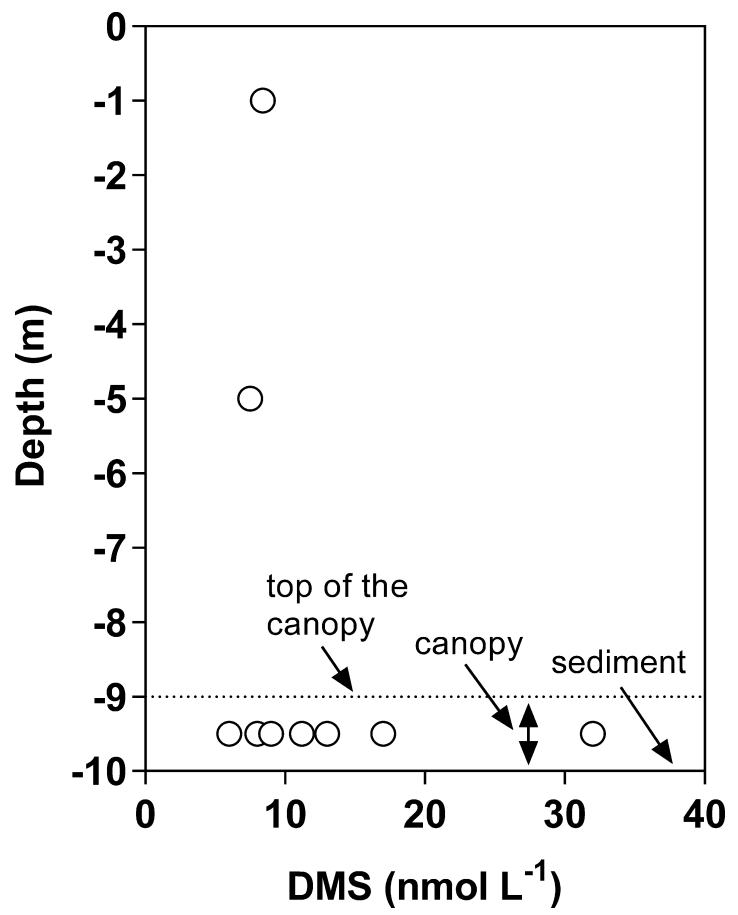

Fig. 4. Variations of dimethylsulfide (DMS, $n m o l L^{-1}$ ) as a function of depth over a Posidonia oceanica meadow at $10 \mathrm{~m}$ depth in the Bay of Revellata (Corsica) in the water column and within the canopy, in August 2012.

changes in DMSP intracellular concentration have been hypothesized to allow algae to cope with short-term osmotic changes (osmoregulation) as by the intertidal algae Enteromorpha intestinalis (Edwards et al., 1988) and the intertidal epiphyte Polysiphonia lanosa (Reed, 1983). The strong increase in DMSP leaf content during summer is inconsistent with the relatively small increase of salinity from winter to summer of $<0.5$ (data not shown), as well as with the strong decrease in summer of DMSP leaf content with depth while salinity usually only decreases by 0.02 from $10 \mathrm{~m}$ to $30 \mathrm{~m}$ (data not shown). DMSP in leaves is not involved in $\mathrm{H}_{2} \mathrm{~S}$ 
detoxification since the leaves are always in oxygen rich environments where $\mathrm{H}_{2} \mathrm{~S}$ is absent, and only roots and rhizomes can be exposed to $\mathrm{H}_{2} \mathrm{~S}$. We carried out a limited number of measurements in roots and rhizomes of $P$. oceanica where the DMSP average content $\left(\sim 0.5 \mu \mathrm{mol} \mathrm{g}_{\mathrm{dw}^{-1}}{ }^{-1}\right)$ was 10 times lower than in leaves. This is lower than in Spartina alterniflora where DMSP in roots is $\sim 5$ times lower than in leaves but still relatively abundant $\left(26 \mu \mathrm{mol} \mathrm{g}_{\mathrm{dw}}{ }^{-1}\right.$, Husband and Kiene, 2007).

$P$. oceanica grows from the base of leaf, hence, the higher DMSP content at the base of the leaf (Fig. 3) could be consistent with a role of DMSP as a herbivore deterrent or as antifouling against epiphytes, as plants allocate costly defenses to parts that contribute the most to fitness and survival (Rhoades, 1979). The fish Sarpa Salpa that accounts for $70 \%$ of herbivory on P. oceanica preferentially consumes the younger sections of the leaves while the sea urchin Paracentrotus lividus (that accounts for the remaining $30 \%$ of herbivory) preferentially consumes the older epiphyte rich sections of the leaves (Prado et al., 2007). Also, herbivory is strongest in shallower parts of the meadows where DMSP leaf content was observed to be higher in summer (Fig. 2). Yet, P. oceanica produces a variety of secondary metabolites such as phenolic compounds (Agostini et al., 1998) that act efficiently as herbivore deterrent (Vergés et al., 2007) or against the settlement of Caulerpa taxifolia (Cuny et al., 1995). Agostini et al. (1998) reported several phenolic substances (acetosyringone, p-anisic acid, ferulic acid, synringaldehyde, protocatechuic acid, phenol, 4-coumaric acid) in P. oceanica tissues with concentrations ranging between 13 and $199 \mu \mathrm{mol} \mathrm{g}_{\mathrm{dw}}{ }^{-1}$. Based on their data, we evaluated the average total concentration of phenolic substances in $P$. oceanica leaves to $\sim 280 \mu \mathrm{mol} \mathrm{g}_{\mathrm{dw}}{ }^{-1}$, hence, $\sim 60$ times higher than the average DMSP leaf content. While a discussion on the exact role of these phenolic substances in $P$. oceanica is outside the scope of the present paper, this suggests that given the lower DMSP content, its role as a grazing deterrent and epiphyte anti-fouling might be marginal compared to phenolic substances. Further, it is acrylate and DMS produced by DMSP cleavage that act as herbivore deterrents, which then requires the synthesis of the enzyme DMSP-lyase. The presence of DMSP-lyase has not been investigated in P. oceanica tissues, but the very high DMSPd concentrations within the canopy (see hereafter) suggests that there is a low cleavage of DMSPd that tends to accumulate. Van Alstyne et al. (2001) have shown that acrylate functions as a deterrent for sea urchins at levels of 0.1 to $2 \%$ fresh mass of macroalgae. Yet, the full conversion of DMSP into acrylate for the average DMSP leaf content of $5 \mu \mathrm{mol} \mathrm{g}_{\mathrm{dw}}{ }^{-1}$ would yield an acrylate level of only $0.02 \%$ fresh mass (assuming a water content of $80 \%$ ). In conclusion, we cannot unambiguously exclude that DMSP acts as a grazer deterrent in $P$. oceanica but considering the low DMSP leaf content it is unlikely to be its main role.

The DMSP leaf content was highest in summer when primary production is seasonally highest (Fig. 1), at shallower depths where primary production is highest (Pergent-Martini et al., 1994), and in the younger sections of the leaves (closest to the base) where primary production is also highest (Alcoverro et al., 1998). The primary production of $P$. oceanica is mainly a function of irradiance. Increased irradiance has been shown to increase intracellular DMSP content in green macroalgae (e.g. Lyons et al., 2010) and phytoplankton (e.g. Slezak and Herndl 2003). These findings suggest that there could be a link between P. oceanica DMSP leaf content and photosynthesis and irradiance. This further suggests that DMSP in $P$. oceanica might act as a carbon overflow mechanism (Stefels et al., 2007) or as an antioxidant for ROS as shown in phytoplankton (e.g. Sunda et al., 2002), macroalgae (e.g. Rix et al., 2012), and in Spartina (Husband et al., 2012; McFarlin and Alber 2013). Dissolved organic carbon exudation has been suggested as an effective carbon overflow mechanism in P. oceanica (Barrón and Duarte 2009), hence, it is likely that the main DMSP role in P. oceanica is an antioxidant for ROS and to cope with oxidative stress as also put forward in recent literature for Spartina (Husband et al., 2012; McFarlin and Alber 2013) and macroalgae (Rix et al., 2012).

The DMS concentration in surface waters of the Bay of Calvi $\left(\sim 8 \mathrm{nmol} \mathrm{L}^{-1}\right)$ was above the range of values usually encountered in summer in the open waters of the Mediterranean ( 0.1 and $5 \mathrm{nmol} \mathrm{L}^{-1}$ ) (Simó and Grimalt 1998), but within the range of values typically encountered in summer in shallow $(<100 \mathrm{~m})$ coastal waters of the North-West Mediterranean ranging between 0.1 and $25 \mathrm{nmol} \mathrm{L}^{-1}$ (Simó and Grimalt 1998; Vila-Costa et al., 2008), yet distinctly lower than values encountered in strongly eutrophic Mediterranean bays with concentrations up to $150 \mathrm{nmol} \mathrm{L}^{-1}$ in summer (Jean et al., 2006). However, within the P. oceanica meadow the DMS concentration was on average 1.7 times higher than above the canopy suggesting a net production of DMS by the meadow that was confirmed by the net accumulation of DMS within a benthic chamber enclosing a $P$. oceanica shoot, resulting in a flux of $17 \mu \mathrm{mol} \mathrm{m}^{-2}$ day $^{-1}$.

The DMSPd fluxes within the incubation chamber of $617 \mu \mathrm{mol} \mathrm{m}^{-2} \mathrm{~d}^{-1}$ were 36 times stronger than the DMS flux $\left(17 \mu \mathrm{mol} \mathrm{m}^{-2} \mathrm{~d}^{-1}\right)$. The initial concentration of DMSPd in the chamber of $877 \mathrm{nmol} \mathrm{L}^{-1}$ was also 63 times higher than the initial concentration of DMS in the chamber $\left(14 \mathrm{nmol} \mathrm{L}^{-1}\right)$. Unlike DMS (Fig. 4), we do not have additional DMSPd measurements within the $P$. oceanica canopy so it is not possible to determine how representative this value might be. Yet, this value is high compared to DMSPd concentrations typically measured in oceanic surface waters, even in highly productive coastal waters such as the Southern Bight of the North Sea (SBNS) where the maximum seasonal DMSPd concentrations is up to $\sim 65 \mathrm{nmol} \mathrm{L}^{-1}$ for a maximum DMS concentration of $\sim 40 \mathrm{nmol} \mathrm{L}^{-1}$ (e.g. Turner et al., 1988). Firstly, it should be noted that the standing stock of DMSP in the biomass of the meadow is very high. The corresponding particulate DMSP (DMSPp) can be roughly estimated at $7800 \mathrm{nmol} \mathrm{L}^{-1}$ in August at $10 \mathrm{~m}$ depth. This value was estimated for a canopy of $1 \mathrm{~m}$ height (approximate length of leaves in August) and DMSP standing stock at $10 \mathrm{~m}$ depth of $7800 \mu \mathrm{mol} \mathrm{m}^{-2}$ (details of computation hereafter). Such DMSPp concentration is very high even for surface waters of highly productive coastal waters such as the SBNS where the highest DMSPp is $1600 \mathrm{nmol} \mathrm{L}^{-1}$ (Turner et al., 1988). So, the high DMSPd concentration within the canopy is consistent with the equally high DMSPp concentration. Secondly, it should be noted that cycling of DMSPd within the canopy does not necessary follow the dynamics typical for surface seawater (planktonic community). For instance, in surface waters a substantial fraction of the removal of DMSPd by lyase activity is related to lyase of phytoplankton origin in Mediterranean coastal waters (Vila-Costa et al., 2008). Within the $P$. oceanica canopy, the presence of phytoplankton should be extremely low due to shading leading to very strong light attenuation (Dalla Via et al., 1998). Within, the P. oceanica canopy, phytoplankton material was found to be mostly detrital, and living cells corresponded to cyanobacteria (Duarte et al., 1999) that are characterized by low DMSP content (Table 1). Further, in August, when DMSPd measurements were carried out, Chl-a in surface waters were extremely low, typically $<0.2 \mu \mathrm{g} \mathrm{L}^{-1}$ (own data not shown; Garrido et al., 2014). Hence, it is possible that DMSPd could accumulate more within the canopy than what is typically observed in the planktonic community of surface waters.

The DMS and DMSPd that accumulated within the meadow could originate from $P$. oceanica but also from epiphyte flora. The epiphyte flora is composed of red, brown and green algae but is dominated in terms of biomass by red coralline algae (Jacquemart and Demoulin 2006) that have a low DMSP content $<0.2 \mu \mathrm{molg}_{\mathrm{dw}^{-1}}{ }^{-1}$ (Kamenos et al., 2008) and a maximum biomass in summer of $0.25 \mathrm{~g}_{\mathrm{dw}}$ per shoot of P. oceanica (Lepoint et al., 2007). Based on a summertime $P$. oceanica biomass of $0.8 g_{d w}$ per shoot 
(Gobert et al., 1995) and a DMSP leaf content of $10 \mu \mathrm{mol} \mathrm{g}_{\mathrm{dw}}{ }^{-1}$ (Fig. 1), the DMSP content related to P. oceanica leaves would be more than 16 times higher than the DMSP content related to red coralline algae epiphytes. Maximum epiphyte diatoms density (dominated by pennate diatoms) in $P$. oceanica leaves is 1600 cells $\mathrm{mm}^{-2}$ (of leaf) (Mazzella and Spinoccia 1992) and would contribute to $0.3 \mu \mathrm{molg}_{\mathrm{dw}}{ }^{-1}$ (of leaf) based on the maximum of DMSP content for pennate diatoms (1.5 pgDMSP cell ${ }^{-1}$, Keller et al., 1989) and an average $P$. oceanica leaf weight of $40 \mathrm{~g} \mathrm{~m}^{-2}$ (of leaf). (Gobert et al., 1995). The DMSP content related to $P$. oceanica leaves would be more than 30 times higher than the maximum DMSP content related to epiphytic diatoms.

The average DMSP leaf content of $P$. oceanica of $5.0 \mu \mathrm{mol} \mathrm{g}_{\mathrm{dw}}{ }^{-1}$ is modest compared to the DMSP content of some Spartina species, of most phytoplankton groups and of the high DMSP producing macroalgae such as Ulvales (although most green, red and brown algae are low DMSP producers). Yet, at the community level, the DMSP standing stock associated to the $P$. oceanica meadow is significant. Indeed, the maximum yearly stock of DMSP associated to phytoplankton can be estimated from the maximum Chl-a concentration typically encountered in the Bay of Revellata of $1.5 \mu \mathrm{g} \mathrm{L}^{-1}$ (data not shown) that is related the spring bloom dominated by diatoms, and the average DMSP:Chl-a ratio of $4 \mathrm{mmol}: \mathrm{g}$ for diatoms reported by Stefels et al. (2007). This yields a maximum yearly stock of DMSP related to phytoplankton of $60 \mu \mathrm{mol} \mathrm{m}^{-2}$ at $10 \mathrm{~m}$ depth (assuming a homogeneous vertical distribution of Chl-a). At $10 \mathrm{~m}$ depth, the maximum yearly stock of DMSP related to P. oceanica meadow can be computed based on the August values (DSMP leaf content of $13 \mu \mathrm{molg}_{\mathrm{dw}}{ }^{-1}$ and a leaf biomass of $600 \mathrm{~g}_{\mathrm{dw}} \mathrm{m}^{-2}$ ). This yields a maximum yearly stock of DMSP of $7800 \mu \mathrm{mol} \mathrm{m}^{-2}, 130$ times higher than the one related to phytoplankton. Furthermore, there is a permanent background DMSP stock of $600 \mu \mathrm{mol} \mathrm{m}^{-2}$ corresponding to winter time DMSP leaf content $\left(2 \mu \mathrm{molg}_{\mathrm{dw}}{ }^{-1}\right)$ and leaf biomass $\left(300 \mathrm{~g}_{\mathrm{dw}} \mathrm{m}^{-2}\right)$, that is still 60 higher than the maximum yearly stock related to phytoplankton. The yearly maximum DMSP content of phytoplankton we estimated is anyway most probably largely over-estimated since the dominant diatoms during the spring phytoplankton bloom reported in the Bay of Revellata by Garrido et al. (2014) have DMSP:Chl-a ratios much lower than the average value used above such as Chaetoceros didynus and Chaetoceros socialis or even DMSP cellular quota that are below detection limit such as Chaetoceros decipiens and Chaetoceros simplex (Keller et al., 1989).

\section{Acknowledgements}

We thank Pierre Lejeune and the Stareso team for logistical support, Marc-Vincent Commarieu, Sylvain Plaza, Gilles Lepoint, Loïc Michel and Sylvie Gobert for assistance during the scuba dives, Jack J. Middelburg, Gilles Lepoint, François Darchambeau and Nathalie Gypens for fruitful discussions, Tom Bell for advise on setting up the GCs, Bruno Delille, Oscan Akkiran, Jessy Thefeld, Sébastien Paulet for help in setting up and testing the GCs, Aurore Aimé and Sébastien Guesse for GC analysis, François Darchambeau for the statistical analysis, Elisabeth Gross (Handling Editor) and two anonymous reviewers for constructive comments on the previous version of the manuscript. This work was funded by the Fonds National de la Recherche Scientifique (FNRS) (DMS Dynamics in the Bay of Calvi, DMSCAL, 2.4.637.10) and the Territorial Collectivity of Corsica and the Rhone-Mediterranean and Corsica Water Agency (STARE-CAPMED - Station of reference and research on change of local and global anthropogenic pressures on Mediterranean ecosystem drifts). AVB is a senior research associate at the FNRS.

\section{References}

Agostini, S., Desjobert, J., Pergent, G., 1998. Distribution of phenolic compounds in the seagrass Posidonia oceanica. Phytochemistry 48, 611-617.

Alcoverro, T., Manzanera, M., Romero, J., 1998. Seasonal and age-dependent variability of Posidonia oceanica (L.) Delile photosynthetic parameters. J. Exp. Mar. Biol. Ecol. 230, 1-13.

Barrón, C., Duarte, C.M., 2009. Dissolved organic matter release in a Posidonia oceanica meadow. Mar. Ecol. Prog. Ser. 374, 75-84.

Cebrián, J., Enríquez, Fortes, S., Agawin, M., Vermaat, N., Duarte, J.E., CM, 1999. Epiphyte accrual on Posidonia oceanica (L.) delile leaves: implications for light absorption. Bot. Mar. 42, 123-128.

Champenois, W., Borges, A.V., 2012. Seasonal and inter-annual variations of community metabolism rates of a Posidonia oceanica seagrass meadow. Limnol. Oceanogr. 57, 347-361.

Cuny, P., Serve, L., Jupin, H., Boudouresque, C.-F., 1995. Water soluble phenolic compounds of the marine phanerogam Posidonia oceanica in a mediterranean area colonised by the introduced chlorophyte caulerpa taxifolia. Aquat. Bot. 52, 237-242.

Dacey, J.W.H., King, G.M., Lobel, P.S., 1994. Herbivory by reef fishes and the production of dimethylsulfide and acrylic acid. Mar. Ecol. Prog. Ser. 112, 67-74

Dacey, J.W.H., King, G.M., Wakeham, S.G., 1987. Factors controlling emission of dimethylsulfide from salt marshes. Nature 330, 643-647.

Dalla Via, J., Sturmbauer, C., Schonweger, G., Sotz, E., Mathekowitsch, S., Stifter, M., Rieger, R., 1998. Light gradients and meadow structure in Posidonia oceanica: ecomorphological and functional correlates. Mar. Ecol. Prog. Ser. 163, 267-278

Dauby, P., Poulicek, M., 1995. Methods for removing epiphytes from seagrasses: SEM observations on treated leaves. Aquat. Bot. 52, 217-228.

Duarte, C.M., Benavent, E., del Carmen Sanchez, M., 1999. The microcosm of particles within seagrass Posidonia oceanica canopies. Mar. Ecol. Prog. Ser. 181, 289-295.

Edwards, D.M., Reed, R.H., Stewart, W.D.P., 1988. Osmoacclimation in enteromorpha intestinalis: long-term effects of osmotic stress on organic solute concentration. Mar. Biol. 98, 467-476.

Garrido, M., Koeck,B, Goffart, A., Collignon, A., Hecq, J.-H., Agostini, S., Marchand, B., Lejeune, P., Pasqualini, V., 2014. Contrasting patterns of phytoplankton assemblages in two coastal ecosystems in relation to environmental factors (Corsica, NW Mediterranean Sea). Diversity 6, 296-322.

Gobert, S., Belkhiria, S., Dauby, P., Havelange, S., Soullard, M., Bouquegneau, J.M., 1995. Variations temporelles de la phénologie et de la composition biochimique de la phanérogame marine Posidonia oceanica en baie de calvi. Bull. Soc. Roy. Sci. Lg. 64, 263-284.

Green, E.P., Short, F.T., 2003. World Atlas of Seagrasses. United Nations Environment Programme, pp. 298.

Husband, J.D., Kiene, R.P., 2007. Occurrence of dimethylsulfoxide in leaves, stems and roots of spartina alterniflora. Wetlands 27, 224-229.

Husband, J.D., Kiene, R.P., Sherman, T.D., 2012. Oxidation of dimethylsulfoniopropionate ( $\mathrm{dmsp}$ ) in response to oxidative stress in Spartina alterniflora and protection of a non-dmsp producing grass by exogenous DMSP + acrylate. Environ. Exper. Bot. 79, 44-48.

Jacquemart, J., Demoulin, V., 2006. Inventaire des macroalgues épiphytes des feuilles de Posidonia Oceanica (L.) Delile dans la baie de la Revellata (Calvi, Corse). Les Éditions de Lejeunia, 71.

Jean, N., Boge, G., Jamet, J.-L., Jamet, D., 2006. Comparison of $\beta$-dimethylsulfoniopropionate (DMSP) levels in two mediterranean ecosystems with different trophic levels. Mar. Chem. 101, 190-202.

Kamenos, N.A., Strong, S.C., Shenoy, D.M., Wilson, S.T., Hatton, A.D., Moore, P.G., 2008. Red coralline algae as a source of marine biogenic dimethylsulphoniopropionate. Mar. Ecol. Prog. Ser. 372, 61-66.

Karsten, U., Kück, K., Daniel, C., Wiencke, C., Kirst, G.O., 1994. A method for complete determination of dimethylsulphoniopropionate (dmsp) in marine macroalgae from different geographical regions. Phycologia 33, 171-176.

Keller, M.D., Bellows, W.K.K., Guillard, R.R.L., 1989. Dimethyl sulfide production in marine phytoplankton. In: Saltzman, E.S., Cooper, W.J. (Eds.), Biogenic Sulfur in the Environment. American Chemical Society, Washington DC, pp. 167-182.

Kiene, R.P., Slezak, D., 2006. Low dissolved DMSP concentrations in seawater revealed by small-volume gravity filtration and dialysis sampling. Limnol. Oceanogr.: Methods 4, 80-95.

Lepoint, G., Jacquemart, J., Bouquegneau, J.-M., Demoulin, V., Gobert, S., 2007. Field measurements of inorganic nitrogen uptake by epiflora components of the seagrass Posidonia oceanica (Monocotyledons, Posidoniaceae). J. Phycol. 43, 208-218.

Lyons, D., Scheibling, R., Van Alstyne, K., 2010. Spatial and temporal variation in DMSP content in the invasive seaweed Codium fragile ssp. fragile: effects of temperature, light and grazing. Mar. Ecol. Prog. Ser. 417, 51-61.

Mazzella, L., Spinoccia, L., 1992. Epiphytic diatoms of leaf blades of the mediterranean seagrass Posidonia oceanica (L.) Delile. Giorn. Bot. Ital 126, $752-754$.

McFarlin, C.R., Alber, M., 2013. Foliar DMSO:DMSP ratio and metal content as indicators of stress in spartina alterniflora. Mar. Ecol. Prog. Ser. 474, 1-13.

Otte, M.L., Wilson, G., Morris, J.T., Moran, B.M., 2004. Dimethylsulphoniopropionate (DMSP) and related compounds in higher plants. J. Exp. Bot. 55, 1919-1925.

Paquet, L., Lafontaine, P.J., Saini, H.S., James, F., Hanson, A.D., 1995. Evidence en faveur de la presence du 3-diméthylsulphoniopropionate chez une large gamme d'angiospermes. Can. J. Bot. 73, 1889-1896. 
Pergent-Martini, C., Rico-Raimondino, V., Pergent, G., 1994. Primary production of Posidonia oceanica in the Mediterranean Basin. Mar. Biol. 120, 9-15.

Prado, P., Tomas, F., Alcoverro, T., Romero, J., 2007. Extensive direct measurements of Posidonia oceanica defoliation confirm the importance of herbivory in temperate seagrass meadows. Mar. Ecol. Prog. Ser. 340, 63-71.

Quinn, G.P., Keough, M.J., 2002. Experimental Design and Data Analysis for Biologists. Cambridge University Press, 537 pp.

Reed, R.H., 1983. The osmotic significance of tertiary sulphonium and quaternary ammonium compounds in marine macroalgae. Br. Phycol. J. 18, 208.

Reynolds, C.S., 2006. The Ecology of Phytoplankton (Ecology, Biodiversity and Conservation). Cambridge Press, pp 551.

Rhoades, D.F., 1979. Evolution of plant chemical defense against herbivores. In: Rosenthal, G.A., Janzen, D.H. (Eds.), Herbivores: Their Interactions with Secondary Plant Metabolites. Academic Press, New York, pp. 3-54.

Rix, L.N., Burdett, H.L., Kamenos, N.A., 2012. Irradiance-mediated dimethylsulphoniopropionate (dmsp) responses of red coralline algae. Estuar. Coast. Shelf Sci. 96, 268-272.

Simó, R., Grimalt, J.O., 1998. Spring-summer emission of dimethyl sulphide from the North-western Mediterranean Sea. Estuar. Coast. Shelf Sci. 47, 671-677.

Slezak, D., Herndl, G.J., 2003. Effects of ultraviolet and visible radiation on the cellular concentrations of dimethylsulfoniopropionate (DMSP) in Emiliania huxleyi (strain 1). Mar. Ecol. Progr. Ser. 246, 61-71.

Stefels, J., 2009. Determination of DMS, DMSP, and DMSO in Seawater. In: Wurl, O. (Ed.). Practical guidelines for the analysis of seawater, pp. 223-234.
Stefels, J., Steinke, M., Turner, S.M., Malin, G., Belviso, S., 2007. Environmental constraints on the production and removal of the climatically active gas dimethylsulphide (DMS) and implications for ecosystem modelling. Biogeochemistry 83, 245-275.

Sunda, W., Kieber, D.J., Kiene, R.P., Huntsman, S., 2002. An antioxidant function for DMSP and DMS in marine algae. Nature 418, 317-320.

Turner, S.M., Malin, G., Liss, P.S., Harbour, D.S., Holligan, P.M., 1988. The seasonal variation of dimethyl sulphide and DMSP concentrations in nearshore waters. Limnol. Oceanogr. 33, 364-375.

Van Alstyne, K.L., Wolfe, G.V., Freidenburg, T.L., Neill, A., Hicken, C., 2001. Activated defense systems in marine macroalgae: evidence for an ecological role for DMSP cleavage. Mar. Ecol. Prog. Ser. 213, 53-65.

Van Alstyne, K.L., Pelletreau, K.N., Rosario, K., 2003. The effects of salinity on dimethylsulfoniopropionate production in the green alga Ulva fenestrata Postels et Ruprecht (Chlorophyta). Bot. Mar. 46, 350-356.

Van Alstyne, K.L., Puglisi, M.P., 2007. DMSP in marine macroalgae and macroinvertebrates: distribution, function, and ecological impacts. Aquat. Sci. 69, 394-402.

Vergés, A., Becerro, M.A., Alcoverro, T., Romero, J., 2007. Experimental evidence of chemical deterrence against multiple herbivores in the seagrass Posidonia oceanica. Mar. Ecol. Prog. Ser. 343, 107-114.

Vila-Costa, M., Kiene, R.P., Simó, R., 2008. Seasonal variability of the dynamics of dimethylated sulfur compounds in a coastal northwest mediterranean site. Limnol. Oceanogr. 53, 198-211. 